\title{
BOROBUDUR DALAM BUDAYA DIGITAL: MERANCANG PODCAST YOUTUBE UNTUK KOMUNIKASI ARKEOLOGI PUBLIK
}

\section{BOROBUDUR IN DIGITAL CULTURE: DESIGN A YOUTUBE PODCAST FOR PUBLIC ARCEOLOGICAL COMMUNICATION}

\author{
Bambang Kasatriyanto ${ }^{1}$, Arif Ardy Wibowo², \\ Balai Konservasi Borobudur ${ }^{1}$, Prodi Ilmu Komunikasi Universitas Ahmad Dahlan ${ }^{2}$ \\ bambangkasatriyanto@gmail.com, arif.wibowo@comm.uad.ac.id
}

\begin{abstract}
ABSTRAK
Pemanfaatan media sosial seperti Youtube perlu dimanfaatkan sebagai sarana pengkomunikasian arkeologi kepada publik. Melalui proses kreatif sebuah konten diskusi publik berwujud podcast mencoba menjadi salah satu media alternatif komunikasi yang bisa menjangkau khalayak ramai. Penelitian ini bertujuan untuk merancang podcact Youtube, yang disebut dengan "Busur", sebagai media komunikasi dan informasi candi Borobudur kepada masyarakat luas. Data bersumber dari wawancaran dengan pengelola "Busur", serta pengamatan pada waktu pengamatan busur. Proses produksi dilakukan dalam tiga tahap, yaitu pra produksi, produksi, dan pasca Produksi. Hasil dari penelitian berupa sebuah model perancangan komunikasi Candi Borobudur berupa Podcast Youtube yang terdiri tiga tahapan. Pertama, pra produksi terdiri dari penentuan ide, penentuan narasumber, dan pembuatan naskah. Kedua, Produksi melakukan persiapan peralatan dan tempat. Tahap terkahira dalah Pasca produksi, yang merupaka editing akhir sebelum diunggah di kanal Youtube. Model yang dihasilkan dapat sebagai referensi publikasi cagar budaya di Indonesia.
\end{abstract}

Kata Kunci: Arkeologi Publik, Komunikasi, Podcast, Youtube

\section{ABSTRACT}

The use of social media such as Youtube can be used as a means to communicating the archeology to the public. Through the creative process, a public discussion content of a podcast tries to become one of the alternative communication media to reach the public in general. This study aims to design a Youtube podcast, which is called "Busur", as a media of communication and information for Borobudur Temple preservation to the wider community. The data comes from interviews with the "Busur" operator, as well as the observations. The production process is carried out in three stages, namely pre-production, production, and post-production. The result of the research is a communication design model for Borobudur Temple preservation in the form of a Youtube Podcast which consists of three stages. First, pre-production consists of determining ideas, sources, and making scripts. Second, Production preparation of equipment and places. The last stage is post-production, which is the final editing before being uploaded on the Youtube channel. The model can be used as a reference for cultural heritage publications in Indonesia.

Keywords: Public Archeology, Communications, Podcasts, Youtube 


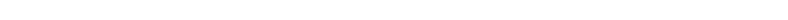

\section{PENDAHULUAN}

Melalui budaya materi manusia dapat mempelajari kehidupan masa lalu, hal tersebut dapat dipelajari melalui perwujudan dari sisa materi yang ditemukan. Memanfaatkan analisis bentuk, model persebaran dari sisa materi kehidupan masyarakat jaman dahulu bisa direkonstruksi untuk mempermudah dalam memahami kehidupan masyarakat pada masa lalu. Melalui tinggalan benda-benda masa lalu yang dikorelasikan dengan rekonstruksi model beserta fungsinya mampu mengambarkan aktivitas masyarakat pada masanya.. Arkeologi merupakan sebuah proses yang berkesinambungan dengan mencari, mengidentifikasi, dan mendiskripsikan kejadian-kejadian di masa lalu kemudian menjelaskan arti kejadian-kejadian tersebut (Sharer \& Ashmore, 1979:11)

Dalam perkembangannya arkeologi mulai menyesuaikan diri dengan kebutuhan jaman, hal ini terjadi seiring dengan meningkatnya kompleksitas permasalahan dalam penelitian arkeologi. Di saat bersamaan penelitian arkeologi juga dipengaruhi dengan berkembangnya teori dan metode penelitian lain di berbagai disiplin ilmu pengetahuan. Di sisi lain masyarakat semakin merasa jauh dengan ilmu arkeologi karena ada jarak yang memisahkan antara pengetahuan para pelaku arkeologi dengan masyarakat. Untuk itu perlu jembatan yang bisa menghubungkan keduanya. Salah satu yang dilakukan adalah publikasi hasil penelitian beserta aktivitas di dalamnya. Para peneliti maupun pelestari diharuskan menyebarluaskan segala aktivitas penelitian arkeologi terutama hasil penelitiannya kepada masyarakat. Upaya penyebarluasan/komunikasi ini sangat penting agar ilmu arkeologi bisa diterima oleh masyarakat. (Joukowsky, 1980). Komunikasi ini bukan hanya tanggung jawab kerja, tetapi di atas semua itu terdapat tanggung jawab moral untuk memastikan bahwa arkeologi diterima oleh masyarakat.. Menyebarluaskan ilmu tentang hasil penelitian dan aktivitas arkeologis sangat penting bagi masyarakat awam bukan hanya kepada kalangan akademik atau kalangan peneliti itu sendiri (Soebadio, 1993/1994).

Saat ini hubungan Ilmu Arkeologi dengan masyarakat mulai terjalain hingga muncul istilah Arkeologi Publik. Beberapa ahli mulai merumuskan dan mendefinisikan seperti apa bentuk dari arkeologi publik, salah satunya Tjahjono Prasodjo (2004) yang menjabarkan arkeologi publik dalam 3 definisi yang meliputi:

1) pengelolaan sumber daya arkeologi dan budaya (dari pengelolaan sumber daya budaya dan upaya konservasi hingga pengelolaan peraturan)

2) bidang kajian yang berkaitan dengan pemberian hasil penelitian arkeologi kepada masyarakat. Publikasi tidak hanya terkait dengan penerbitan, tetapi juga mencakup bentuk model publikasi lain seperti pameran, museum, poster, film, dan sosialisasi arkeologi.

3) studi interaksi arkeologi dengan masyarakat secara khusus. Interaksi dua arah dari arkeologi pada masyarakat maupun masyarakat kepada arkeologi..

Khusus pengertian yang ketiga mengenai studi interaksi arkeologi dengan masyarakat secara khusus dibutuhkan saluran-saluran untuk menyebarluaskan hasil penelitian dan aktivitas didalamnya agar informasi mengenai penelitian arkeologi maupun aktivitas pelestariannya dapat tersalurkan kepada masyarakat. Hal ini bertujuan untuk memberikan keselararasan kepada masyarakat dalam memahami informasi yang diberikan, mengurangi perbedaan pandangan sehingga mampu membangun motivasi untuk beraktivitas berdasarkan informasi yang diperoleh.(Pace, 2002 dalam Widodo, 2012 : 35).

Perkembangan Teknologi Informasi dan Komunikasi pada dua dekade belakangan tumbuh dengan sangat cepat, hal ini ditandai dengan terciptanya berbagai inovasi-inovasi di berbagai bidang yang semakin mempercepat arus informasi. Salah satu inovasi yang ikut berkembang adalah media sosial. Perkembangan media sosial telah menciptakan pengaruh yang sangat signifikan bagi kehidupan masyarakat dimana media sosial telah melunturkan sekat-sekat wilayah dan semakin menghilangkan jarak yang memisahkan antar individu. Media sosial telah menjadi wahana baru bagi masyarakat untuk saling berinteraksi meskipun 
dalam tempat yang saling berjauhan. Anthony Mayfield (2008) menyebutkan bahwa media sosial dipahami sebagai media jaringan (online) yang memungkinkan kelompok tertentu untuk terlibat dengan berbagai media/perangkat yang digunakan oleh komunitas di seluruh dunia. Media sosial telah menjadi sarana penghubung hampir setiap aspek kehidupan manusia saat ini, mulai dari bidang teknologi informasi hingga bidang budaya hingga arkeologi. Selama lebih dari dua dekade, media sosial telah menjadi mesin yang efektif untuk dinamika pembelajaran arkeologi, tidak hanya sebagai ruang intim untuk pertemuan dan pertukaran ide, tetapi juga sebagai media interaksi antara arkeologi dan masyarakat (Ririmasse : 2018).

Salah satu media sosial yang belakangan ini sedang naik daun adalah konten berbagi video Youtube. Pada tahun 2021 menurut hasil riset Statista pengguna Youtube diprediksi meningkat hingga angka 1,8 miliar orang. Hal ini didasari karena meningkatnya nilai manfaat Youtube yang awalnya hanya sebagai tempat berbagi dan mencari hiburan, kini menjelma menjadi tempat untuk belajar dan berbagi informasi. Dari data Think with Google mengatakan 86 persen pengguna Youtube mengakses untuk memperoleh informasi yang sedang "trending" atau viral. Youtube menjadi jejaring sosial paling populer yang dalam konteks pembelajaran menjadi salah satu media pendidikan (Mujianto : 2019). Konten Youtube yang sarat akan informasi yang dikemas dalam bentuk diskusi antara host dan narasumber yang saat ini sedang banyak diminati adalah podcast. Podcast merupakan rekaman diskusi audio tentang topik tertentu, seperti pendidikan, perjalanan, atau isu-isu yang sedang berkembang yang awal mulanya hanya berbentuk audio. Podcast banyak ditemukan dibeberapa situs berbagi seperti iTunes dan Spotify, namun seiring berjalannya waktu mulai berkembang menjadi konten Youtube yang berbentuk audio video.

Salah satu keuntungan podcast adalah reusability dan replaying sehingga bisa dimanfaatkan kapanpun dan dimanapun karena media ini bisa dilihat secara langsung ataupun diunduh terlebih dahulu. Podcast juga tidak tergantung pada teknologi tertentu karena bisa diputar mengunakan berbagai media seperti MP3 Player, MP4 Player, Smartphone, laptop, dan media lainnya. Keuntungan lain adalah media ini sangat mudah untuk disebarluaskan karena tiap-tiap materi memiliki alamat website yang berbeda-beda yang bisa dibagikan melalui banyak media sosial lain seperti Facebook, Whasapp, instagram, dan media sosial lainnya.

Potensi podcast sebagai media publikasi yang besar bisa menjadi salah satu alternatif media atau saluran komunikasi yang efektif untuk menyampaikan informasi terkait arkeologi atau aktivitas pelestarian cagar budaya. Sifatnya yang tidak terikat oleh media pemutar tertentu dan bisa diputar kapan saja dan dimana saja menjadikan media ini sangat fleksibel. Hal ini dimanfaatkan Balai Konservasi Borobudur dengan membuat Podcast Youtube yang berjudul "BUSUR" (Ngobrol Soal Borobudur) sebuah konsep diskusi publik yang mengulas apapun mengenai borobudur dari berbagai sudut pandang. Tantangan dalam pengembangan podcast busur sebagai media publikasi baru yang memerlukan pengenalan masif agar diketahui oleh masyarakat. Hal lain yang menjadi tantangan adalah tema cagar budaya merupakan salah satu tema di antara ribuan tema yang tengah berlomba-lomba mencari pengikut untuk memperoleh informasi yang bermanfaat bagi mereka. Selain itu pemanfaatan internet di Indonesia tidak berbanding lurus dengan manfaat yang didapat oleh masyarakat, terutama di kalangan anak muda. Hal ini dikarenakan buruknya literasi digital yang didapat dan kurangnya pengetahuan tentang konten yang positif di internet (Rahmawan : 2018). Dari uraian diatas beberapa rumusan masalah yang menjadi pembahasan dalam tulisan ini adalah (1) bagaimana Podcast Youtube menjadi media alternatif komunikasi arkeologi kepada publik(2) bagaimana model rancangan Podcast Busur yang digunakan Balai Konservasi Borobudur menjadi referensi publikasi cagar budaya di Indonesia. 


\section{PEMBAHASAN}

\section{Podcast Youtube Sebagai Media Komunikasi Arkeologi Kepada Publik Komunikasi dan media sosial}

Sebagai makhluk sosial manusia selalu melakukan interaksi satu dengan lainnya. Interaksi dilakukan dengan komunikasi untuk mempermudah manusia menjalani kehidupan bersosialnya, sehingga Komunikasi sangat penting bagi manusia karena orangorang terhubung satu sama lain melalui komunikasi.. Harold D. Lasswell dari Canagara (2011: 2-3), ada tiga fungsi dalam komunikasi dalam masyarakat yakni keinginan untuk mengubah warisan sosial, keinginan untuk beradaptasi dengan lingkungan, dan mengendalikan lingkungan. Komunikasi adalah proses belajar manusia untuk memahami sesuatu, dan komunikasi memudahkan manusia untuk memahami dan mengontrol lingkungannya. selain itu manusia harus menyesuaikan diri dengan lingkungannya, untuk memudahkan dalam mengontrol lingkungan,. Proses adaptasi manusia terhadap lingkungan juga dipahami melalui proses komunikasi. adaptasi juga digunakan untuk melanggengkan keberadaannya dengan mengubah warisan sosialnya, yang dapat terlihat dalam proses komunikasi dari orangtua kepada anaknya atau sebuah bentuk komunikasi yang terjadi pada proses belajar mengajar di sekolah.

Everett M. Rogers dari Cangara menjelaskan bahwa komunikasi adalah proses mengkomunikasikan ide dan informasi dari sumber yang bertujuan untuk mengubah perilaku seseorang kepada satu orang atau lebih. Melalui pemahaman tersebut, komunikasi untuk perubahan perilaku dapat dijelaskan sebagai sikap acuh tak acuh terhadap isu-isu yang berkaitan dengan warisan budaya jika pada awalnya mereka tidak memahaminya. Kedua, setelah proses komunikasi, akan terjadi perubahan minat dan perilaku masyarakat, baik secara sendiri maupun bersama-sama, terhadap berbagai isu yang berkaitan dengan warisan budaya terkait dengan hasil kegiatan penelitian dan konservasi.Komunikasi efektif ketika dua pihak yang berkomunikasi - pengirim dan penerima pesan - memiliki pengalaman yang sama. Ini dapat bekerja secara efektif ketika sering dipahami bersama untuk mengurangi distorsi pesan komunikasi.. David K. Berlo merumuskan komunikasi menggunakan istilah SMCR, yang merupakan singkatan dari source (pengirim), message (pesan), channel (saluran/media) dan penerima (receiver). Menurut Berlo (Mulyana, 2007:162), sumber adalah pihak (individu atau kelompok) yang menghasilkan pesan, pesan adalah penjabaran gagasan ke dalam kode-kode simbolik seperti bahasa atau simbol, saluran yang merupakan sarana/media komunikasi, dan penerima adalah orang dan objek komunikasi.

Perkembangan Teknologi Informasi dan Komunikasi pada dua dekade belakangan tumbuh dengan sangat cepat, hal ini ditandai dengan terciptanya berbagai inovasi-inovasi di berbagai bidang yang semakin mempercepat arus informasi. Ada dua aspek teknologi informasi dan komunikasi yaitu teknologi informasi dan teknologi komunikasi. Teknologi informasi mencakup segala sesuatu yang berhubungan dengan proses informasi, penggunaan sebagai alat, operasi dan manajemen. Sedangkan teknologi komunikasi adalah penggunaan alat bantu untuk mengolah dan mentransfer data dari satu perangkat ke perangkat lainnya (Puskur Balitbang, 2007). Oleh karena itu, TIK adalah tentang proses, manipulasi, pengelolaan, dan transmisi informasi antar media menggunakan teknologi tertentu. Salah satu inovasi yang ikut berkembang adalah media sosial. Perkembangan media sosial telah memberikan dampak yang besar bagi kehidupan masyarakat dimana media sosial telah melunturkan sekat-sekat wilayah dan semakin menghilangkan jarak yang memisahkan antar individu. Media sosial telah menjadi wahana baru bagi masyarakat untuk saling berinteraksi meskipun dalam tempat yang saling berjauhan. Anthony Mayfield (2008) menjelaskan bahwa media sosial dikatakan sebagai media jaringan (online) yang memungkinkan suatu kelompok tertentu untuk berpartisipasi dalam berbagai media/perangkat yang digunakan di seluruh komunitas global.Komunikasi dapat terjadi kapan saja, di mana saja, tanpa memandang jarak, ruang dan waktu, serta status sosial yang tidak dapat dibedakan lagi. Berkat kehadiran 
Youtube, Twitter, Facebook, Google, dll, masalah komunikasi jarak jauh telah hilang, di mana orang dapat berinteraksi tanpa harus bertatap muka. Media sosial telah mengubah dunia secara drastis dan setiap level komunikasi akhirnya terintegrasi ke dalam sebuah wadah yang dikenal sebagai jejaring sosial/media sosial.Pada akhirnya dunia arkeologi juga masuk dalam salah satu dari ribuan topik yang muncul dalam media sosial. Ruang baru ini telah menjadi wadah untuk saling bertukar gagasan dan pengetahuan arkeologi dan segala aktivitasnya. Salurannya yang sangat luas membuat gagasan dan pengetahuan arkeologi bisa dibagikan atau diteruskan kepada masyarakat luas. Di era digital saat ini, jejaring sosial tidak hanya digunakan oleh individu dan kelompok yang bergerak di bidang arkeologi, tetapi juga oleh organisasi resmi seperti UPT kementerian, universitas, museum, lembaga penelitian, dan organisasi resmi lainnya. Banyak organisasi secara aktif menggunakan media sosial sebagai cara untuk berinteraksi dengan masyarakat umum dan dunia secara keseluruhan. Akhirnya, media sosial yang awalnya dianggap media informal menjadi media informasi yang memberikan pengetahuan arkeologi kepada masyarakat umum.

Seperti halnya Balai Konservasi Borobudur sebagai Unit Pelayanan Teknis Direktorat Jenderal Kebudayaan, selain memanfaatkan website yang menginduk pada portal web Kementerian Pendidikan dan Kebudayaan sebagai media komunikasi resmi juga memanfaatkan beberapa media sosial antara lain facebook (@BalaiKonservasiBorobudur), Twitter (@bkborobudur), instagram (@konservasiborobudur) dan Youtube (@Balai Konservasi Borobudur). Pemanfaatan media sosial sangat membantu menyebarluaskan segala informasi yang dipublikasikan oleh Balai Konservasi Borobudur sehingga lebih banyak orang yang mengenal dan mengetahui segala aktivitas dan hasil penelitian baik arkeologi maupun bidang ilmu lainnya.

\section{Youtube sebagai media sosial}

Mayfield menjelaskan ada beberapa karakteristik media sosial antara lain (1) Partisipan (participation), (2) Keterbukaan (openness), (3) Percakapan (conversation), (4) Masyarakat (community), dan (5) Keterhubungan(connectedness). Karakteristik bermedia sosial pertama adalah Partisipan (participation). Media sosial kini telah menjelma sebagai wadah berinteraksi yang tidak bisa dipisahkan dengan kehidupan masyarakat di Indonesia, interaksi aktif para pengguna media sosial di Indonesia menunjukkan perkembangan signifikan. Data tahunan dari Hootsuite (We Are Social) yang menunjukkan tren di internet dan media sosial memperlihatkan bahwa pada tahun 2020 dari total jumlah penduduk indonesia 272,1 juta, jumlah pengguna internet mencapai 175,4 juta dan pengguna media sosial aktif sebanyak 160 juta. Berdasarkan data tersebut bahwa dalam mengakses media, pengguna di Indonesia menghabiskan waktu yang bervariasi (Tabel 1). Rata-rata setiap hari waktu menggunakan internet melalui perangkat apa pun mencapai 7 jam, 59 menit dan ratarata setiap hari waktu menggunakan media sosial melalui perangkat apa pun mencapai 3 jam, 26 menit.

Presentase Platforms media sosial yang paling aktif di Indonesia (lihat Tabel 2), pengguna Youtube sebanyak $88 \%$ dari jumlah populasi, pengguna Whatsapp sebanyak $84 \%$ dari jumlah populasi, pengguna Facebook sebanyak 82\% dari jumlah populasi, dan pengguna Instagram sebanyak 79\% dari jumlah populasi. Hal ini menunjukkan bahwa media sosial mempunyai pengaruh yang sangat besar bagi masyarakat Indonesia. Dari data tersebut partisipan Youtube masyarakat Indonesia mencapai 140,8 juta, sebuah angka yang sangat besar sehingga potensi untuk menyebarkan informasi cagar budaya terbuka sangat lebar. 
Tabel 1. Durasi Penggunaan Media Masyarakat Indonesia

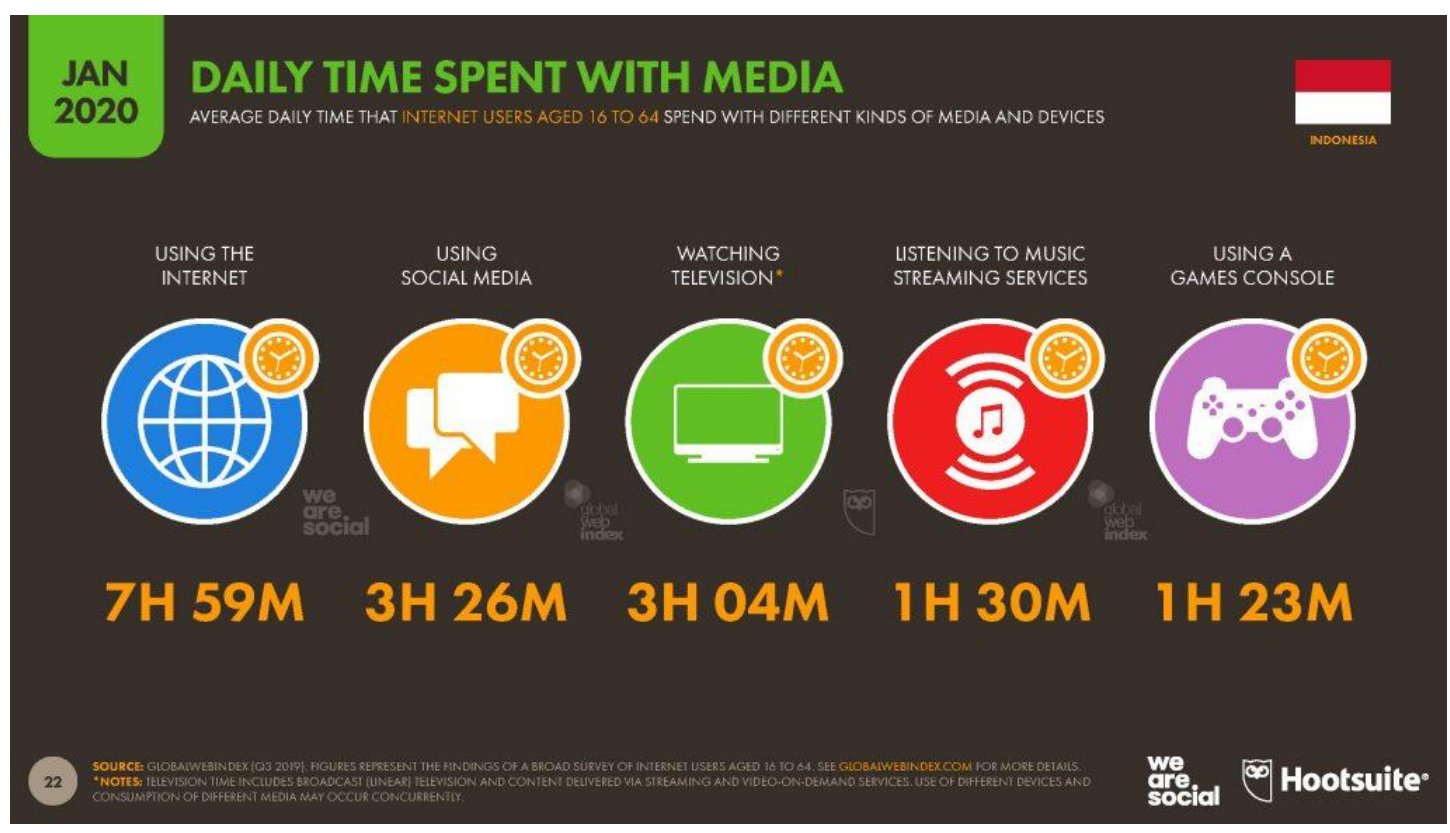

Sumber: Hootsuite (We are Social): Indonesian Digital Report 2020

Tabel 2. Persentase Pengguna Internet Berdasarkan Platform

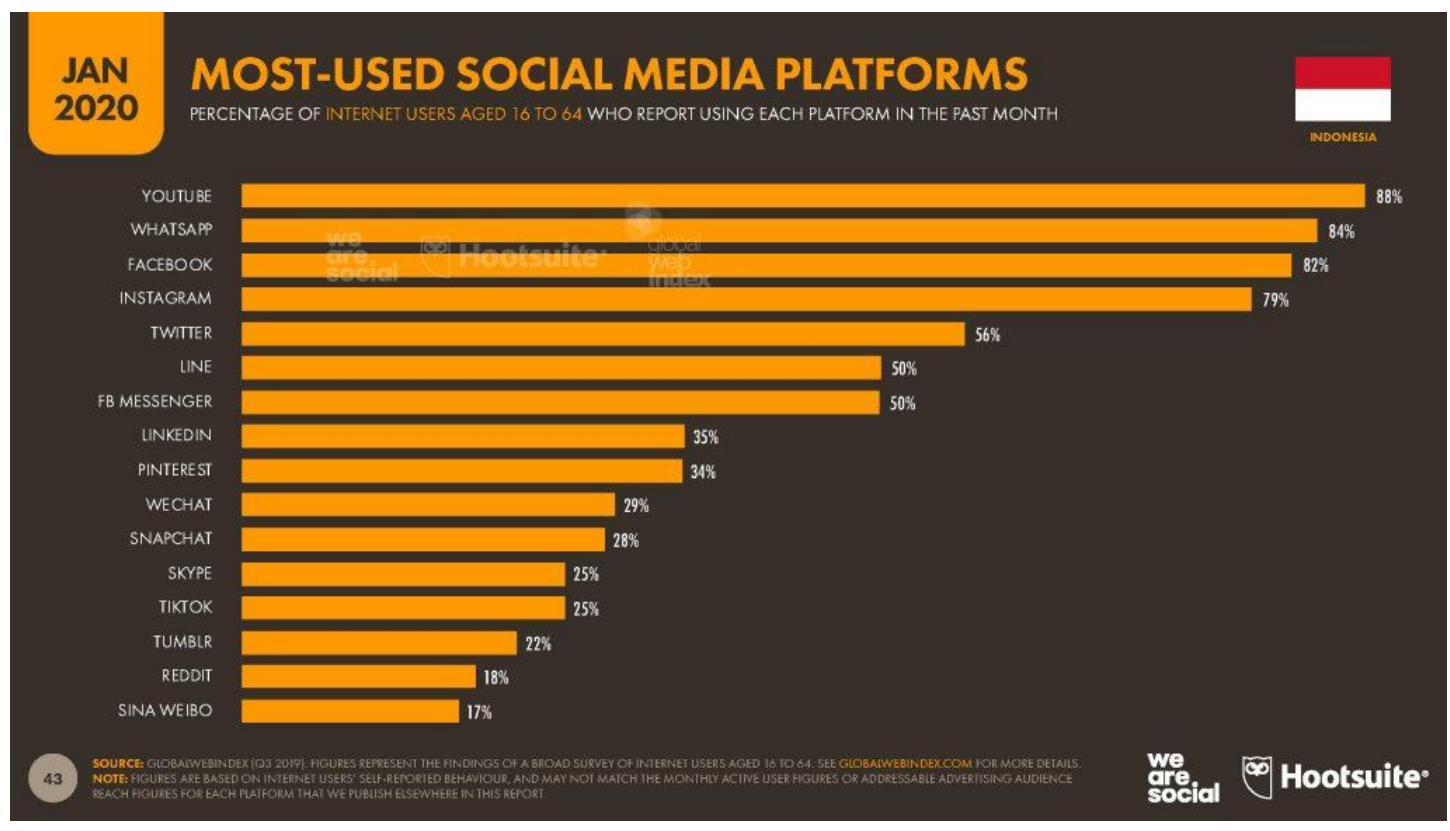

Sumber: Hootsuite (We are Social): Indonesian Digital Report 2020

Karakteristik kedua adalah keterbukaan (openness), Media Sosial harus bersifat inklusif dimana setiap orang bisa mengakses bahkan saling berinteraksi. Media sosial tidak boleh bersifat eksklusif sehingga setiap orang bisa mendapatkan informasi yang ada dalam media sosial, meskipun tetap dalam batasan nilai-nilai kepantasan dan moral yang tinggi. 
Youtube sangat konsen dengan hal ini, dimana setiap orang bisa mengakses video dengan batasan-batasan yang telah ditentukan, bahkan untuk menjaring pengguna anak-anak Youtube telah menyediakan konten khusus dalam wujud Youtube Kids, media ini berisi konten-konten yang ramah terhadap anak dengan aturan-aturan yang sangat ketat untuk bisa berbagi konten.

Karakteristik yang ketiga adalah Percakapan (conversation), Media sosial hadir tidak seperti media konvensional yang hanya mampu menyampaikan informasi dua arah. Media sosial mampu menampung lebih dari dua orang untuk berinteraksi secara langsung tanpa ruang dan batas sehingga memungkinkan komunikasi dari berbagai sisi. Youtube menyediakan kolom chat dimana setiap orang bisa berinteraksi secara bebas dalam mengeluarkan pendapatnya dalam kurun waktu yang hampir bersamaan sehingga bisa membuat interaksi bagi para penggunanya berjalan lebih dinamis.

Karakteristik keempat adalah Masyarakat (community). Salah satu pemegang peranan terpenting dalam media sosial adalah adanya masyarakat atau komunitas. Peran komunitas sangat penting karena merupakan inti dalam perkembangan media sosial. Komunitas tertentu dapat membentuk suatu ikatan emosional hingga bisa saling berbagi informasi. Dalam Youtube masyarakat bisa memilih secara bebas informasi yang mereka butuhkan. Untuk memudahkan pengguna dalam mendapatkan informasi secara berkala, Youtube memberikan mode berlangganan pada setiap akun yang bebas dipilih sesuai selera yang mereka inginkan. Istilah berlangganan atau Subsciber menjadi salah satu indikator bahwa sebuah akun Youtube bisa dikatakan berhasil karena mampu mungumpulkan massa untuk mengikuti segala informasi dari akun tersebut. Semakin banyak yang berlangganan semakin banyak pula informasi yang bisa disebarkan.

Karakteristik yang kelima adalah keterhubungan (connectedness). Media sosial mampu memberikan kemudahan untuk mengakses informasi serta melakukan komunikasi dengan siapapun. Youtube mampu menciptakan interaksi antara pemilik konten dengan para follower bahkan muncul keterikatan atau keterhubungan diantara mereka sehingga interaksi terjadi secara dinamis.

Besarnya populasi media sosial di Indonesia sebagai wadah untuk berinteraksi, semakin berpeluang untuk membentuk perilaku-perilaku baru di masyarakat. Opini Publik menjadi sangat mudah dibentuk untuk menjadi kekuatan baru yang memiliki dampak yang besar dalam kehidupan masyarakat. Informasi-informasi yang muncul dalam media sosial telah menciptakan perilaku baru bagi penggunanya sesuai dengan interpretasi mereka masing-masing.

\section{Podcast Youtube sebagai media komunikasi arkeologi publik}

Podcast merupakan salah satu bentuk dari sekian banyak model konten di Youtube. Pada saat ini banyak kreator konten mulai mengadopsi podcast yang mulai naik daun karena sangat diminati oleh masyarakat. Podcast berasal dari istilah iPod, sejenis perangkat yang dirilis oleh Apple, dan istilah Cast adalah singkatan dari Broadcastyang berarti rekaman asli berupa audio atau video yang ada di internet dalam bentuk program berseri. Rekaman diskusi bisa beisi tentang topik tertentu, seperti pendidikan, perjalanan, atau isu-isu yang sedang berkembang yang awal mulanya hanya berbentuk audio. Podcast banyak ditemukan dibeberapa situs berbagi seperti iTunes dan Spotify, namun seiring berjalannya waktu mulai berkembang menjadi konten Youtube. Beberapa Youtuber Indonesia sukses mengorbitkan podcast mereka melalui Youtube yang membahas berbagai hal, salah satunya Podcast Deddy Corbuzier di Channel Youtubenya.

Salah satu keuntungan podcast adalah reusability dan replaying sehingga bisa dimanfaatkan kapanpun dan dimanapun karena media ini bisa dilihat secara langsung ataupun diunduh terlebih dahulu. Podcast juga tidak tergantung pada teknologi tertentu karena bisa diputar mengunakan berbagai media seperti MP3 Player, MP4 Player, 
Smartphone, laptop, dan media lainnya. Keuntungan lain adalah media ini sangat mudah untuk disebarluaskan karena tiap-tiap materi memiliki alamat website yang berbeda-beda yang bisa dibagikan melalui banyak media sosial lain seperti Facebook, Whatsapp, instagram, dan media sosial lainnya.

Arkeologi bisa memanfaatkan podcast Youtube sebagai salah satu media alternatif komunikasi kepada publik, apalagi tuntutan jaman dimana arus informasi berjalan sangat cepat dan kebutuhan masyarakat akan informasi sangat tinggi. Melalui podcast, arkeologi bisa dijabarkan ke dalam beberapa topik yang lebih luas dengan menghadirkan narasumbernarasumber yang kompeten di bidangnya yang bisa diakses dari mana saja dan kapan saja. Hal ini sejalan dengan tujuan arkeologi publik bahwa publikasi hasil penelitian dan segala aktivitas didalamnya sangat penting untuk dilakukan. publikasi ini bukan hanya menyelesaikan tanggung jawab kerja akan tetapi sebagai bentuk gerakan moral agar ilmu arkeologi bisa diterima oleh masyarakat. menyebarluaskan ilmu tentang hasil penelitian dan aktivitas arkeologis sangat penting bagi masyarakat awam bukan hanya kepada kalangan akademik atau kalangan peneliti dan pelestari cagar budaya itu sendiri (Soebadio, 1993/1994).

Semakin berkembangnya jaman dan kemajuan di bidang teknologi menuntut arkeologi untuk dapat menyesuaikan diri dengan keadaan dengan membuat terobosanterobosan agar tidak terjebak pada kebiasaan lama. Podcast Youtube bisa menjadi salah satu media alternatif Untuk lebih menghadirkan dunia arkeologi di tengah-tengah kehidupan masyarakat dalam berbagai bidangnya. Diskusi-diskusi ringan mengenai aktivitas arkeologi, pembahasan isu-isu terkini, pengenalan temuan-temuan, dan menjelaskan pesan yang ada dalam tinggalan-tinggalan budaya bisa menjadi bahan yang sangat menarik bagi masyarakat awam sehingga informasi yang diperoleh bisa membawa orang merekonstruksi dalam pikirannya mengenai peristiwa yang terjadi di masa lalu. (Widodo, 2012: 36-37).

Salah satu contoh podcast yang dikembangkan oleh Balai Konservasi Borobudur adalah BUSUR "Ngobrol Seru Soal Borobudur". Kegiatan ini muncul tidak terlepas dari semakin tingginya pengguna Youtube yang menjadi pangsa pasar yang cukup menjanjikan apalagi kondisi pandemi covid-19 mengharuskan semua kegiatan yang biasanya dilakukan secara luring (luar jaringan) terpaksa harus dilakukan dengan daring (dalam jaringan). Hal itu membuat rasa optimis bahwa program ini bisa menjadi alternatif publikasi cagar budaya. Seluruh konten yang dibahas selalu berhubungan dengan Borobudur dimulai dari cerita mengenai danau purba di sekitar candi Borobudur, perkembangan konservasi di Indonesia, melihat kehidupan masyarakat jawa kuno melalui relief Candi Borobudur, manfaat Warisan dunia UNESCO dan manfaatnya bagi Candi Borobudur, melihat Candi Borobudur dalam perpektif dokumentasi, candi Borobudur dalam ingatan arsip dunia, dan beberapa hasil kebudayaan yang ada di sekitar candi Borobudur. Total sudah 8 seri yang telah ditayangkan di akun Youtube Balai Konservasi Borobudur telah berbuah manis (Tabel 3). Podcast busur telah menarik ratusan peminat untuk melihat kegiatan ini secara langsung, bahkan ketika telah selesai diunggah jumlah penonton terus bertambah hingga lebih dari seribu kali dilihat.

Podcast Youtube kedepan akan menjadi media yang cukup menjanjikan sebagai sebuah media sosial yang terus berkembang. Selain pangsa pasar pengguna Youtube yang sangat besar kemudahan dalam mengakses, reusability dan replaying yang membuat orang tidak terikat oleh waktu-waktu tertentu untuk melihat podcast. Selain itu tampilan podcast yang lebih santai memudahkan masyarakat awam untuk memahami arkeologi dibandingkan dengan diskusi formal yang cenderung serius. Obrolan yang santai lebih membuat orang yang melihat lebih akrab dan personal dengan tema-tema yang dibahas sehingga memudahkan pemahaman masyarakat. 
Tabel 3. Jumlah Penoton Busur

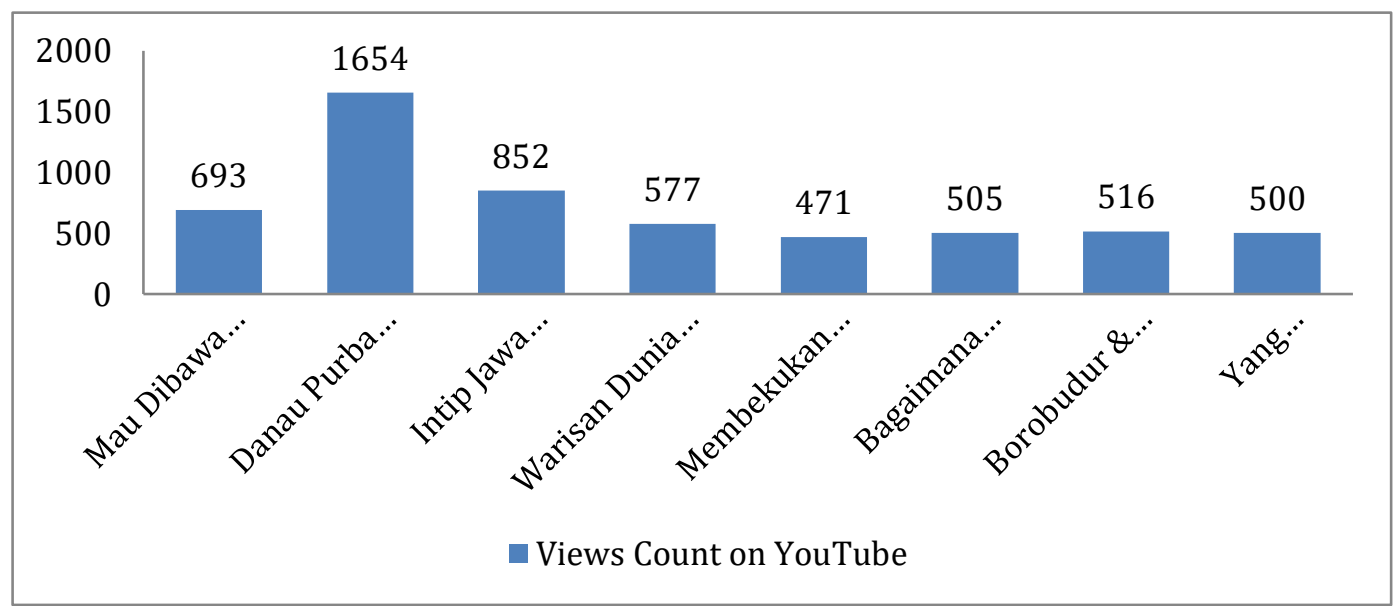

\section{Rancangan Podcast Youtube "Busur” Menjadi Media Publikasi Arkeologi Yang Menarik}

Podcast Youtube merupakan salah satu model konten kreatif yang saat ini mulai berkembang. Berbeda dengan model podcast yang pada awalnya berbentuk audio, podcast Youtube membutuhkan proses audio visual oleh karena itu proses pembuatannya tidak akan terlepas dari persiapan alat-alat pendukung proses produksi siaran. Penyiaran atau broadcasting adalah proses dimulainya suatu pertunjukan mulai dari penyiapan bahan produksi, produksi dan penyiapan bahan siaran hingga pemirsa menerima siaran di suatu tempat. Penyiaran tidak semata merupakan kegiatan yang bermotif ekonomi, tetapi juga memiliki peran sosial yang tinggi sebagai sarana komunikasi.. Dalam arkeologi medium ini dapat dimanfaatkan sebagai wadah penyampaian ide, gagasan dan atau opini untuk membujuk atau menggiring orang agar memahami arkeologi dan akhirnya merubah cara pandang dan perilakunya.

Pada dasarnya proses produksi persiapan podcast hampir sama dengan persiapan siaran di televisi hanya saja proses dilakukan lebih sederhana dimana siaran podcast melalui media Youtube melalui jaringan internet sedangkan televisi menggunakan pemancar sendiri. Proses yang dilakukan antara lain Pra Produksi, Produksi, dan Pasca Produksi.

\section{Pra Produksi}

Praproduksi adalah persiapan perencanaan untuk mempersiapkan apa yang dibutuhkan dalam proses produksi. Proses ini melibatkan pertemuan tim untuk mengumpulkan ide dan gagasan berdasarkan target audiens acara, menyiapkan skrip yang diperlukan selama produksi, persiapan produksi, dan diakhiri dengan hubungan keluar untuk melaksanakan kerjasama produksi.Perencanaan kegiatan yang diawali dari perumusan ide dan gagasan yang kemudian dituangkan dalam naskah/script. Sebuah naskah mempunyai peran yang sangat penting dalam produksi sebuah program audio visual. Fungsi naskah dalam produksi program audio visual adalah sebagai konsep dasar (basic concept), pengarah (direction), dan acuan (reference). Pada umumnya naskah berisi gambaran atau deskripsi tentang pesan atau informasi yang akan disampaikan, alur diskusi, dan acuan bagi tim produksi dalam melaksanakan proses produksinya. Beberapa tahapan penulisan naskah biasanya dimulai dari perumuskan ide, riset, penulisan outline, penulisan naskah, reviu naskah, dan finalisasi naskah.

Perumusan materi Podcast Busur diawali dengan menentukan tema-tema besar yang biasanya dikaitkan dengan hari-hari besar, agenda khusus yang sedang berlangsung, atau isu 
yang sedang ramai di bicarakan oleh masyarakat. seperti peringatan hari purbakala, hari warisan dunia, hari pendidikan nasional, Pekan Kebudayaan Nasional, atau isu mengenai para pekerja seni dan budaya yang bertahan di tengah pandemi covid-19. pembahasan tema yang terkait dengan even-even tertentu atau yang sedang hangat untuk menciptakan hubungan kedekatan dengan masyarakat sehingga materi yang disajikan dapat terhubung dan mudah diterima oleh masyarakat. setelah diperoleh tema besar dikerucutkan pada materimateri yang ingin disampaikan dan menentukan narasumber yang kompeten untuk membahas materi yang telah dipersiapkan. untuk memancing partisipasi dari masyarakat beberapa hari sebelum proses produksi, dipublikasikan poster melalui media sosial dimana masyarakat bisa mengajukan pertanyan atas tema yang akan dibahas. setelah beberapa materi diperoleh akan dirumuskan dalam beberapa outline dan dikembangkan dalam suatu naskah yang menjadi acuan bagi host, narasumber, dan tim produksi.

Persiapan berikutnya adalah sarana produksi yakni sarana yang menjadi penunjang utama proses produksi. Produksi audio visual memerlukan alat dengan kualitas standar yang dapat menghasilkan gambar dan suara yang bagus. Peralatan utama yang dibutuhkan untuk bahan produksi adalah satu set alat perekam video, satu set alat perekam, dan satu set peralatan lighting. Peralatan perekaman gambar membutuhkan standar tertentu agar bisa menghasilkan gambar yang bagus. Saat ini pemanfaatan kamera smartphone pun sebenarnya sudah bisa dimanfaatkan untuk merekam video namun terdapat batasan-batasan tertentu. Tidak seperti produksi televisi yang menggunakan kamera-kamera khusus yang cenderung mahal, pemanfatan kamera-kamera DSLR, mirrorless, dan webcam yang memiliki resolusi tajam, setidaknya 720p sudah cukup bagus untuk produksi Youtube. Harga kamera-kamera tersebut juga cenderung lebih terjangkau dengan kualitas gambar yang cukup mumpuni. Untuk kamera DSLR dan mirrorless juga bisa dipasangkan dengan berbagai lensa untuk menghasilkan efek gambar yang lebih beragam. Selain kamera sarana pendukung untuk pengambilan gambar adalah tripod sebagai tempat sandaran kamera.

Proses produksi podcast Youtube "Busur" memanfaatkan kamera yang sudah dimiliki oleh Balai Konservasi Borobudur yakni kamera DSLR Canon, mirrorless Sony dan webcam Logitech yang memiliki resolusi gambar 720p (Gambar 1). Penggunaan ketiga kamera yang berbeda ini terkait dengan software untuk proses produksi yakni Open Broadcasting Software yang merupakan perangkat lunak gratis dan terbuka untuk merekam

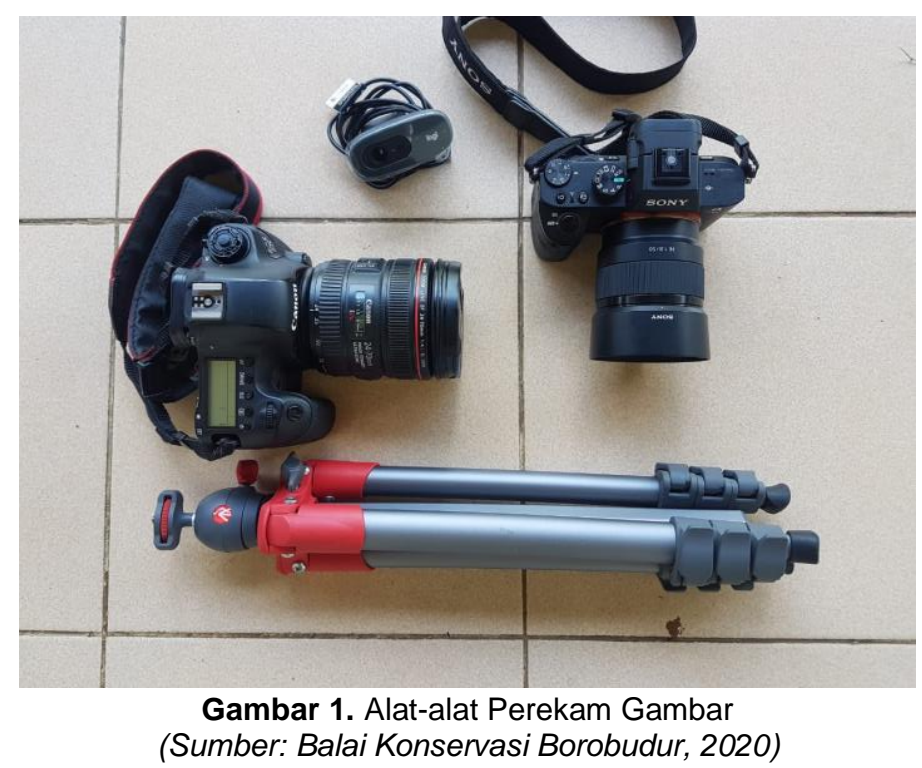

video dan streaming langsung melalui Youtube. Pengunaan tiga kamera atau biasa disebut 
multi camera untuk memperoleh variasi gambar agar tidak terkesan monoton. Pemilihan produksi audio visual dengan sistem multi kamera diantaranya: Pertama bahwa sebuah diskusi meskipun telah mengunakan naskah hanya akan dilakukan sekali adegan terlebih jika siaran yang dilaksanakan secara langsung. Konsep siaran langsung sering diartikan sebagai "gambaran hidup yang tidak bisa diulang”. Ketiga kamera akan mengambil gambar setiap adegan secara bersamaan dalam waktu yang sama, hanya angle gambar akan dibuat bervariasi agar lebih nyaman ketika dilihat oleh penonton. Pengambilan multi kamera juga sangat memudahkan untuk proses editing jika pengambilan gambar untuk perekaman terlebih dahulu. Kedua gambar yang dibuat terlihat lebih dinamis dan tidak membosankan karena hasil yang terlihat menjadi lebih terorganisir dengan baik. Hal ini dikarenakan transisi gambar dilakukan langsung dan tidak berulang sehingga menghasilkan gambar yang berbeda baik dari sudut kamera dan pencahayaan. Ketiga, audio sama pentingnya dengan streaming langsung seperti halnya video. Audio yang direkam langsung di studio atau di luar ruangan memiliki keunggulan dibandingkan konten yang mengandalkan dubbing. Rekaman langsung memungkinkan audiens Anda pemirsa mengalami percakapan secara langsung, bahkan saat merekam acara. keempat adalah waktu magis atau peristiwa penting yang tidak bisa terulang kembali. Saat mengambil gambar dengan beberapa kamera, bisa dengan mudah mempertimbangkan momen terbaik yang diambil dengan beberapa kamera. untuk mendukung penggunaan sistem multi-kamera dibutuhkan juga banyak orang sebagai juru kamera.. (Naratama: 2004)

Salah satu unit peralatan pendukung berikutnya adalah pencahayaan untuk menghasilkan gambar yang lebih dramatis. Dalam pengambilan gambar menggunakan kamera, Keberadaan sumber cahaya yang merupakan elemen dasar fotografi sangatlah penting. Hasil representasi fotografi dalam istilah light painting dan light painting menjadikan cahaya sebagai faktor terpenting. Tanpa cahaya, kamera tidak dapat menghasilkan gambar.. Kamera bisa menangkap gambar disebabkan hasil dari pantulan cahaya yang mengenai benda tersebut. Dasar dalam pencahayaan audio visual juga berasal dari bidang fotografi yang memanfaakan cahaya sebagai sumber utama dalam menangkap gambar mengunakan kamera. Fotografi sendiri berasal dari kata Yunani 'photos' yang berarti cahaya dan 'Grafo' yang berarti lukisan/tulisan sehingga dalam bahasa Inggris disebut "Photography".Keberadaan cahaya saat memotret adalah untuk membantu komposisi, menciptakan suasana dan kesan, atau membuat gambar lebih bertekstur, dramatis, dan umumnya berdimensi. (Agnes, 2015:83).

Pegaturan tata cahaya podcast Youtube "Busur" juga memanfaatkan beberapa alat tambahan apalagi yang pengambilan gambar yang dilakukan didalam ruangan atau studio. Kamera membutuhkan cahaya yang cukup untuk menghasilkan video berkualitas tinggi. Dibutuhkan satu set perlengkapan yang cocok untuk mencapai pencahayaan yang sempurna. Konsep pencahayan didalam studio mengunakan konsep pencahayaan 3 Titik (3-Point Lighting) yakni main light, fill light dan background light (lampu utama, cahaya pengisi, dan lampu latar). Main light memiliki fungsi sebagai lampu utama, sehingga main light jauh lebih terang dibandingkan dengan fill light. Di ruangan gelap main light adalah sumber cahaya yang menerangi subjek.. Main light menjadi penganti cahaya matahari sebagai pusat cahaya. Posisikan lampu utama kira-kira 15 hingga 45 derajat ke arah subjek, kiri atau kanan sesuai kebutuhan.. Agar gambar tidak terasa datar digunakanlah fill light dan background light sebagi pengisi cahaya dan muncul dimensi kedalaman. Fill light memudahkan untuk melihat subjek dan melembutkan pancaran main light. Fill light biasanya berseberangan dengan main light. Fill light biasanya berada di depan subjek dan secara diagonal di belakang kamera. Kombinasi pencahayaan main light dan fill light dapat menciptakan tampilan yang cerah dan alami. Hal ini menciptakan nuansa yang tidak merata sehingga paparan cahaya agar terlihat seimbang akan melembutkan cahaya. Background light berfungsi untuk menerangi latar agar cahayanya tidak terlalu jauh atau terlalu kontras dengan subyek. Lampu latar ditempatkan di 
belakang subjek untuk menerangi subjek dari belakang. Fungsi lain dari penggunaan lampu latar adalah untuk melengkapi cahaya yang dipancarkan dari main light dan fill light. Lampu latar dapat menciptakan garis terang di sekitar subjek dan memberi sorotan tajam untuk menghasilkan tampilan 3-dimensi.

Salah satu unit terpenting dalam podcast adalah unit peralatan perekam suara, karena suara merupakan inti pokok dalam menyebarkan informasi dalam sebuah podcast.

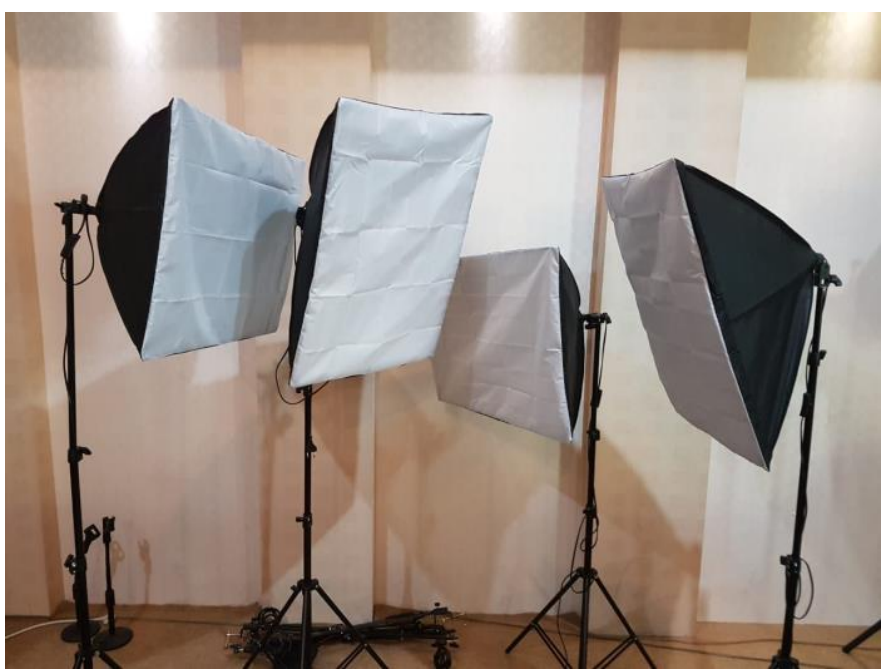

Gambar 2. Beberapa lampu yang digunakan untuk pencahayaan podcast (Sumber: Balai Konservasi Borobudur, 2020)

Bisa dibayangkan jika podcast Youtube ada gambar namun tidak ada suara, sehingga membutuhkan peralatan perekam yang standar agar bisa menghasilkan suara yang optimal. Untuk mempersiapkan alat-alat perekaman suara dibutuhkan beberapa alat pendukung yaitu; pertama komputer / laptop dengan spek yang memadai. Komputer atau laptop dengan kemampuan prosesor dan memori yang besar dibutuhkan karena pada saat perekaman mengunakan perangkat lunak menguras kemampuan komputer. Untuk podcast Youtube "Busur" selain difungsikan untuk perekaman komputer dimanfaatkan untuk siaran langsung atau streaming Youtube dan proses editing gambar dan suara, sehingga menggunakan PC dengan spek yang cukup tinggi yakni Lenovo Legion dan hasilnya, suara rekaman berkualitas tinggi dapat diperoleh.. Kedua perangkat lunak perekaman untuk studio.. Komponen penting berikutnya adalah aplikasi atau perangkat lunak perekaman yang menyediakan fasilitas antarmuka untuk mengelola rekaman di komputer. Terdapat perangkat lunak perekaman gratis dan ada yang berbayar. Semakin mahal perangkat lunak, semakin banyak fitur dan utilitas yang ditawarkannya. Dua dari aplikasi perekaman gratis yang paling populer dan banyak digunakan adalah Audacity dan GarageBand. Perangkat lunak rekaman suara dan studio rekaman tersebut dapat memberikan Anda hasil rekaman terbaik saat merekam. Aplikasi di atas juga dapat digunakan untuk merekam audio yang dibutuhkan untuk keperluan podcast seperti perekaman jingle dan lagu pembuka dan penutup. Yang ketiga adalah aplikasi mixing audio untuk studio. Sama seperti perangkat lunak perekaman, perangkat lunak pencampuran audio dapat menggunakan aplikasi mixer audio gratis atau berbayar.. Beberapa software audio mixer antara lain Adobe Audition, Audacity, Abletion Live, dan beberapa software lainnya.

Keempat audio interface yakni perangkat yang menghubungkan mikrofon dan instrumen ke PC melalui mixer.. Pada dasarnya audio interface berfunsi sama dengan sound card untuk merekam, tetapi kualitas perekaman jauh lebih baik dibanding sound card bawaan. Podcast Youtube "Busur" menggunakan audio interface dengan 4 saluran input dan 2 saluran output untuk membuat rekaman stereo. Kelima audio mixer untuk studio 
rekaman. Mixer adalah bagian terpenting dari studio rekaman. Semua input audio dari instrumen dan mikrofon masuk melalui mixer dan diteruskan ke komputer melalui audio interface. Keenam adalah studio monitor dan headphone. Studio monitor adalah perangkat speaker yang dibutuhkan untuk mendengarkan musik hasil pencampuran dan editing sebelum membuat hasil audio. Tidak seperti speaker konvensional, studio monitor menghasilkan suara dengan respon frekuensi yang benar-benar datar. Artinya hasil rekaman yang terdengar lewat studio monitor persis sama dengan suara digital yang tersimpan tanpa ada pengaturan atau penyesuaian frekuensi. Fungsi studio monitor bisa digantikan dengan perangkat headphone. Selain jauh lebih kecil dan lebih murah, menggunakan headphone relatif lebih fleksibel karena dapat melakukan mixing kapan saja tanpa mengganggu orang lain. Dengan headphone, juga lebih mudah dilakukan untuk meminta orang lain ikut memonitor hasil rekaman. Terakhir adalah mikrofon, salah satu alat terpenting untuk kebutuhan rekaman. Podcast Youtube "Busur" mengunakan beberapa mic untuk proses perekaman. Untuk perekaman outdoor mengunakan wireless mic yang tingkat sensitivitasnya lebih rendah untuk mengurangi noise suara yang berasal dari sekitar lokasi perekaman.

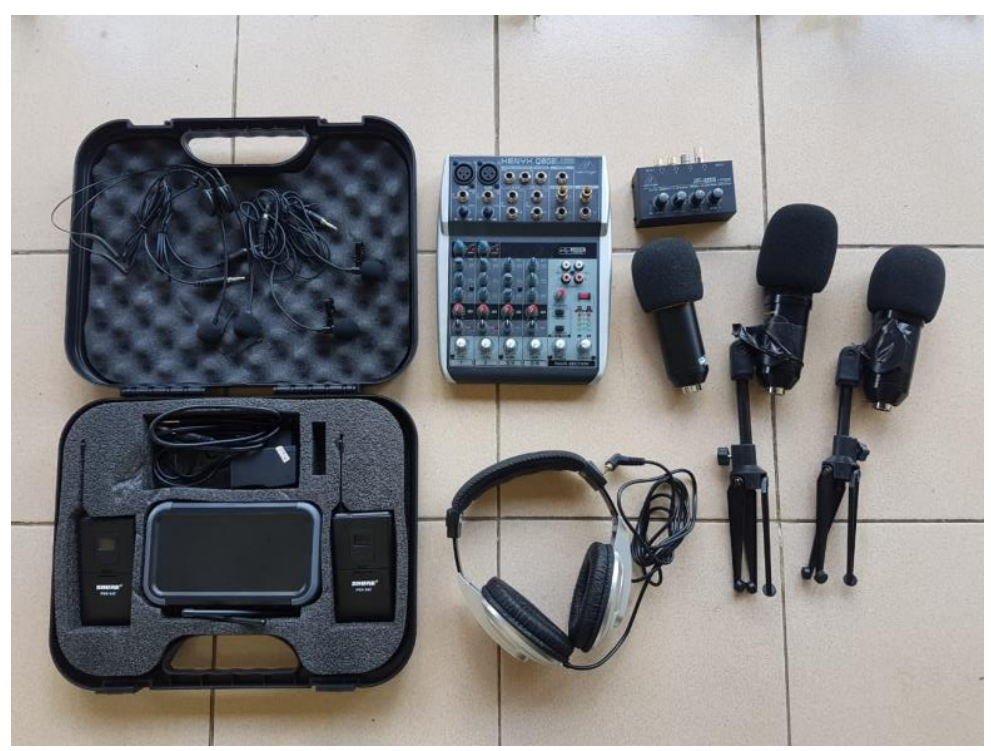

Gambar 3. Alat-alat Perekam suara

(Sumber: Balai Konservasi Borobudur, 2020)

Tahapan berikutnya adalah persiapan tempat yang akan digunakan untuk melaksanakan produksi podcast. Tempat memegang peranan penting dalam produksi podcast, karena tempat menjadi ruang interaksi antara host dengan narasumber sehingga diharapkan minim dari gangguan. Standar ruang untuk podcast seperti studio siaran yang kedap suara, terdapat ac, dan dilengkapi dengan peralatan produksi. Balai Konservasi Borobudur dalam proses produksinya memanfaatkan ruang sidang yang memang sudah didesain kedap suara, memiliki desain interior ruangan yang cukup memadai dan sudah memiliki ac. Selain fasilitas tersebut untuk proses produksi ditambahkan meja dan kursi yang nyaman untuk host beserta narasumber. pernak-pernik cagar budaya dan tanaman hias juga dimanfaatkan untuk mendukung estetika gambar. Untuk perekaman outdoor juga dilakukan dengan mencoba meminimalisir gangguan dengan menyekat beberapa tempat sementara waktu selama kegiatan perekaman berlangsung. Hal ini digunakan agar fokus para penonton tidak terpecah oleh gangguan suara atau lalu lalang orang berjalan.

Setelah persiapan alat selesai satu hal yang harus dsiapkan adalah orang yang mengoperasionalkan segala peralatan tersebut. Manusia (brainware) merupakan bagian yang penting dalam menjalankan podcast. Untuk menjalankan podcast Youtube "Busur" 
dibutuhkan pembuat naskah, pembawa acara, kameraman, penata cahaya, penata suara, operator komputer, dan direktur lapangan. Setiap orang bertanggung jawab atas perannya masing-masing dan saling bekerja sama dalam sebuah tim.

\section{Produksi}

Setelah proses perencanaan naskah hingga persiapan alat selesai, pelaksanaan produksi dimulai. Pembawa acara dan narasumber menempati tempat yang sudah disediakan bekerja sama dengan seluruh kru mencoba mewujudkan apa yang direncanakan dalam kertas menjadi susunan gambar dan susunan suara dilengkapi dengan penataan cahaya untuk menghasilkan karya audio visual yang menarik.

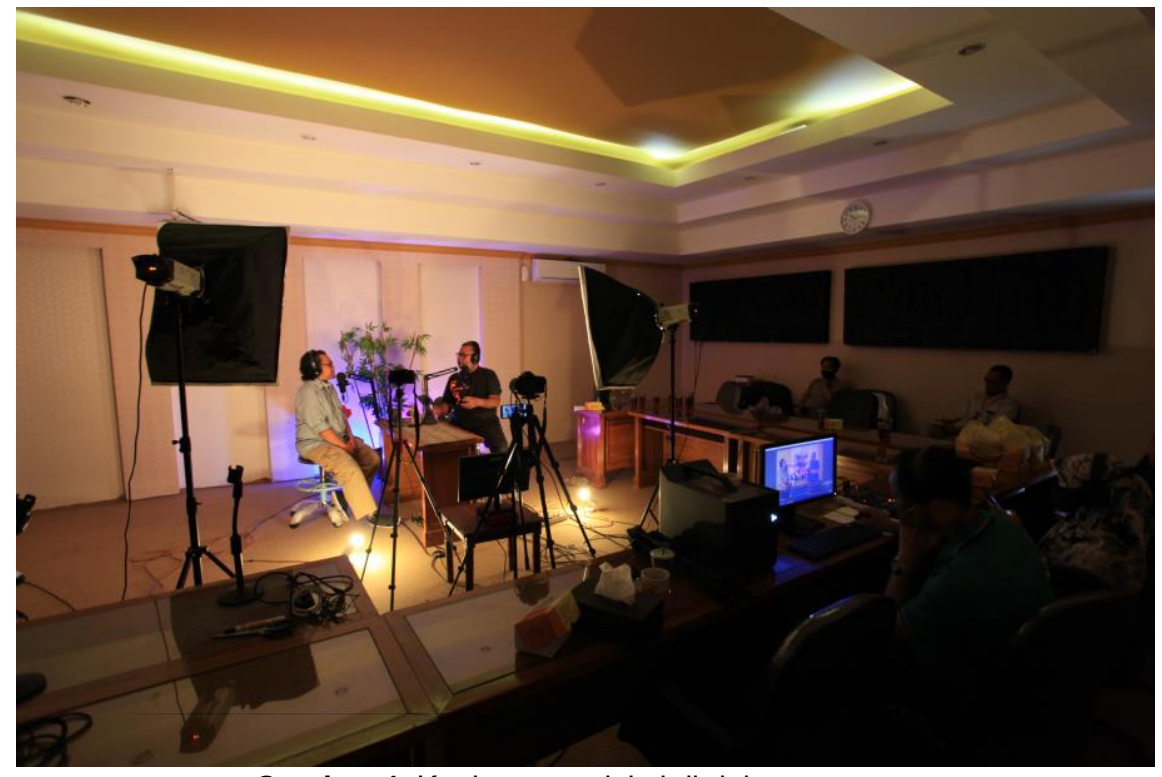

Gambar 4. Kegiatan produksi di dalam ruangan

(Sumber: Balai Konservasi Borobudur, 2020)

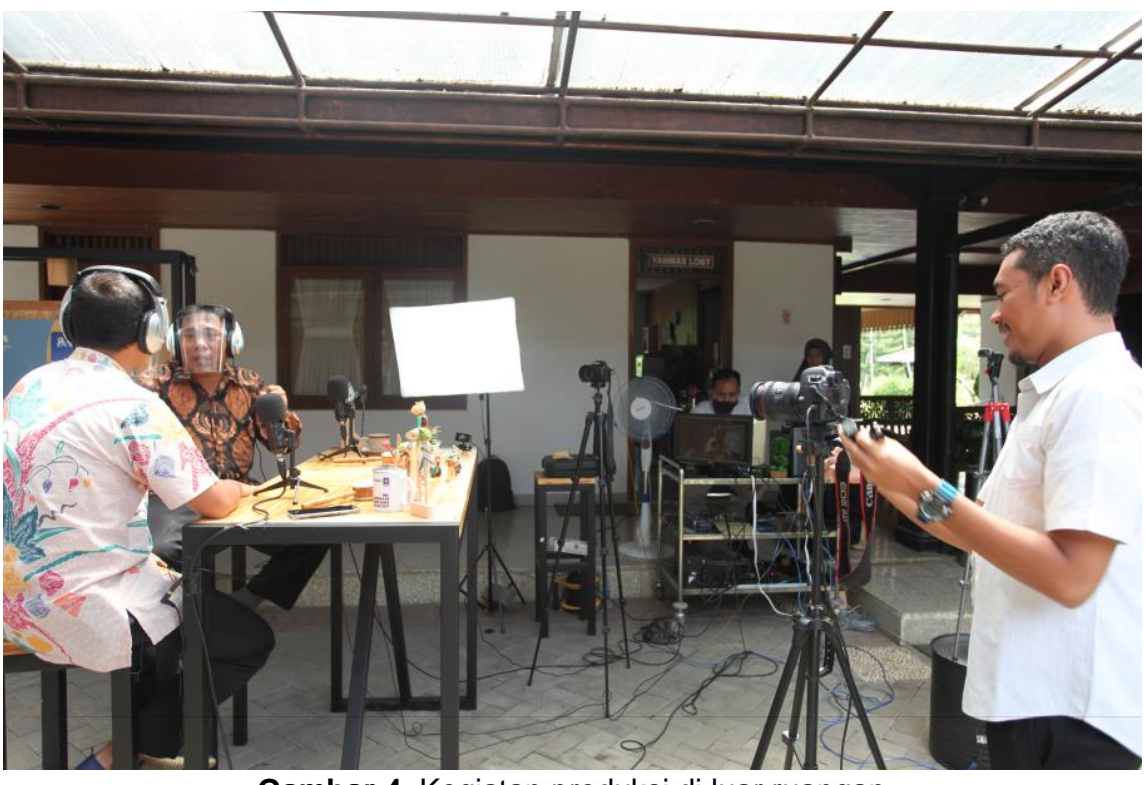

Gambar 4. Kegiatan produksi di luar ruangan

(Sumber: Balai Konservasi Borobudur, 2020) 


\section{Pasca-produksi}

Pada proses pasca produksi langkah terakhir sebelum gambar di upload di Youtube adalah editing. Editing adalah sebuah proses menata hasil rekaman gambar dan suara menjadi suatu karya audio visual yang baru dan enak untuk dilihat. Terdapat lima langkah dalam editing gambar (Bahri, 2019: 61-63). Pertama Editing Offline dengan Teknik Analog. Setelah proses perekaman gambar dan suara selesai, penulis script atau naskah membuat catatan(logging) Semua catatan didasarkan pada gambar yang direkam dan diambil. Catatan (logging) perekaman (gambar digital, gambar kode menampilkan detik, menit, dan jam) dan hasil setiap pengambilan gambar. Berdasarkan catatan (logging) sutradara membuat potongan kasar yang disebut potongan offline berdasarkan ide naskah berdasarkan narasi.Kemudian skrip yang diedit dibuat untuk memudahkan editor, termasuk skrip, gambar, dan kode waktu yang diedit. Hasil tangkapan pertama dan skrip yang diedit kemudian diserahkan ke editor untuk diedit secara online.. Kedua Editing Online dengan Teknik Analog. Berdasarkan skrip editing, editor mengolah hasil pengambilan gambar yang asli. perpaduan setiap gambar dan adegan (scene) dibuat tepat berdasarkan catatan timecode dalam naskah editing. Demikian pula sound asli dimasukkan dengan proporsional. Setelah editing online sudah siap, proses berlanjut dengan mixing antara gambar dan suara.

Ketiga adalah Mixing atau percampuran gambar dengan suara. Merekam suara dari narasi dan musik yang dapat membangun suasana kemudian disusun kedalam hasil , editing online sesuai dengan arahan yang telah dibuat dan disepakati dalam naskah editing. Keseimbangan beberapa elemen suara seperti sound effect, suara asli, suara narasi dan musik dibuat secara proporsional dan seimbang satu dengan lainnya sehingga tidak saling mengganggu dan terdengar jelas. Sesudah proses mixing dan secara menyeluruh produksi juga selesai, biasanya diadakan preview.

Keempat Editing Offline dengan Teknik digital atau non-Linier. Editing ini menggunakan komputer khusus untuk editing. Hal pertama yang dilakukan dengan menginput seluruh hasil perekaman ke dalam hardisk. Proses memasukkan data ini disebut capturing atau digitizing, yaitu mengubah hasil gambar menjadi bentuk file. Dalam editing non-Linier dengan sistem digital, penyusunan tidak harus mengikuti urutan adegan seperti dalam sistem analog. Setelah data gambar tertata dengan rapi kemudian dirangkai agar susunan gambar yang telah selesai digabungkan dapat terlihat secara utuh, proses ini disebut render. Tahapan berikutnya dilakukan screening untuk memperoleh gambaran hasil secara utuh. Setelah selesai, bahan offline dalam komputer langsung dibuat online. Terakhir Editing Online dengan Teknik Digital. Editing online dengan teknik digital merupakan penyempurnaan hasil editing offline dalam komputer, sekaligus mencampurkan musik ilustrasi atau efek gambar dan suara (sound effect atau narasi) yang harus dimasukkan. Sesudah semua sempurna, hasil online kemudian siap diupload ke Youtube.

\section{Promosi podcast}

Promosi podcast merupakan salah satu strategi komunikasi agar media komunikasi arkeologi untuk publik dikenal oleh banyak orang. Sangat disayangkan jika podcast yang sudah dikemas menarik tidak banyak yang melihat. Promosi ini sangat penting dimana tema arkeologi atau pelestarian cagar budaya merupakan salah satu tema diantara ribuan tema yang berada di Youtube. Salah satu promosi yang dilakukan podcast Youtube "Busur" dengan mempromosikan kegiatan melalui media sosial Balai Konservasi Borobudur baik instagram, facebook, twitter, dan laman website kemdikbud. Selain itu permintaan untuk unggah ulang di akun-akun media sosial yang memiliki jumlah pengikut besar seperti akun kemdikbud atau akun budaya saya untuk memperlebar jangkauan. Pemanfaatan media sosial tersebut lebih mudah dilakukan dan bisa langsung menyasar kepada masyarakat yang memiliki tingkat ketertarikan terhadap arkeologi dan pelestarian cagar budaya. Strategi lainnya adalah memanfaatkan akun-akun media sosial, grup-grup whatsapp atau jejaring sosial lainnya yang 
dimiliki oleh karyawan kantor untuk membantu mempromosikan poster-poster kegiatan sehingga daya jangkaunya lebih banyak. Strategi promosi ini dilakukan karena lebih mudah dan murah namun bisa menyasar masyarakat yang luas.

\section{KESIMPULAN}

Kemajuan teknologi informasi dan komunikasi mendorong manusia untuk cepat beradaptasi dan memanfatkan segala inovasi-inovasi yang berkembang. Kemunculan media sosial yang telah mengubah pola komunikasi manusia dengan menghilangkan sekat jarak dan ruang sehingga manusia bisa dari mana saja dan kapan saja berkomunikasi. Tidak terlepas dalam arkeologi yang dituntut untuk mengkomunikasikan segala apa yang telah dihasilkan dan segala aktivitas didalamnya. Pemanfaatan media sosial sebagai saluran komunikasi seperti podcast Youtube bisa menjadi salah satu alternatif komunikasi kepada publik. Dengan kemudahan dalam berkreasi membuat konten audio visual, kemudahan dalam penyebaran konten, kemudahan akses, bisa diputar dengan berbagai media, daya jangkau yang sangat besar, dan bisa dilihat kapanpun dimanapun menjadi keuntungan tersendiri dalam memanfaatkan media ini.

Podcast Youtube "Busur" dalam proses produksi mengacu pada kaidah penyiaran yang menjadi dasar dalam membuat karya audio visual yang menarik. Proses perekaman mengunakanalat perekam gambar kamera DSLR, mirrorless, dan webcam dengan resolusi 720 p yang menghasilkan gambar yang optimal. Selain itu didukung dengan peralatan perekaman suara dan tata cahaya yang standar untuk menghasilkan karya audio visual yang menarik.

Beberapa tantangan yang muncul dalam pembuatan konten youtube antara lain

1. Selektif dalam memilih instrumen musik karena terkait dengan Hak Kekayaan Intelektual agar konten yang telah upload di Youtube dihapus karena melanggar hak cipta.

2. Kreatif dalam mengemas konten karena semakin cepatnya arus informasi yang beredar dalam kehidupan masyarakat membuat mereka lebih cenderung ingin mendapatkan informasi yang cepat mereka tangkap sehingga jika masyarakat menganggap konten tersebut tidak memberikan manfaat akan mereka tinggalkan.

3. Membuat Promosi yang menarik karena konten yang bertema kebudayaan merupakan tema yang menarik untuk dibahas, namun tema ini merupakan salah satu tema diantara ribuan tema yang ada di dalam Youtube

4. Melakukan kolaborasi dalam membuat konten bersama pembuat konten yang memiliki banyak pengikut. Dengan kolaborasi ini akan memperluas jangkauan informasi yang disebarkan terutama kepada pengikut pembuat konten. Untuk itu perlu selektif dalam memilih pembuat konten yang disesuaikan dengan rencana konten yang akan dibuat

5. Konsistensi dalam membuat konten, hal ini sangat penting untuk menjaga para pengikut menantikan konten yang mereka butuhkan. Konsistensi berupa format video, tokoh yang khas, karakter tampilan yang unik, dan jadwal rutin konten.

6. Memanfaatkan media sosial lain untuk memperluas daya jangkau koten youtube yang diproduksi.

Dengan berbagai tantangan yang selalu muncul dalam upaya pengkomunikasian arkeologi kepada publik, proses kreatif dan selalu tanggap teknologi harus dilakukan agar lebih banyak masyarakat yang bisa mengetahui mengenai arkeologi dan aktivitasnya sehingga bisa merubah cara pandang dan cara berperilaku mereka. 


\section{DAFTAR PUSTAKA}

Bahri, Andini Nur. Dasar-dasar Broadcasting. Sumatera Utara: Universitas Islam Negeri Medan. 2019.

Cangara, H. Hafied. Pengantar Ilmu Komunikasi. Jakarta: PT. Raja Grafindo Persada, 2011.

Gunawan, Agnes Paulina. 2015. "Pencahayaan dalam Studio Fotografi”. Dimensi, Vol. 12No 1. (2015): 81-102.

Joukosky, Martha. 1980. A Complete Manual of Field Archaeology. Tools and Techniques of Field Work for Archaeologists. New Jersey: Prenfice-Hale, Inc.

Mayfield, Antony. What Is a Sosial Media?. London: iCrossing. 2008.

Mujianto, Haryadi. "Pemanfaatan Youtube Sebagai Media Ajar Dalam Meningkatkan Minat Dan Motivasi Belajar,” Jurnal Komunikasi Universitas Garut: Hasil Pemikiran dan Penelitian, vol. 5, no. 1, pp. 135-159, 2019, doi: http://dx.doi.org/10.10358/jk.v5i1.588

Mulyana, D. ILMU KOMUNIKASI Suatu Pengantar, Bandung: PT REMAJA ROSDAKARYA. 2008.

Naratama. Menjadi Sutradara Televisi dengan Single dan Multi Camera. Jakarta: Grasindo, 2004 .

Prasodjo, Tjahjono. Arkeologi Publik. Makalah disampaikan dalam rangka Pelatihan Pengelolaan Sumberdaya Arkeologi Tingkat Dasar di Trowulan. 2004.

Pusat Kurikulum. Balitbang. Naskah Akademik Kajian Kebijakan Kurikulum Mata Pelajaran TIK. Jakarta: Departemen Pendidikan Nasional. 2007.

Rahmawan, Detta. dkk. "Potensi Youtube Sebagai Media Edukasi Bagi Anak Muda," Edulib journal of library and information science, vol. 8, no. 1, pp. 81-98, 2018, doi: https://doi.org/10.17509/edulib.v8i1.11267.g7280

Ririmasse, Marlon. “Arkeologi, Publik, Dan Media Sosial Di Maluku,” KALPATARU, Majalah Arkeologi, vol. 27, no. 1, pp. 31-44, 2018, doi: https://doi.org/10.24832/kpt.v27i1.552

Sharer, RobertJ dan Wendy Ashmore. Fundamentals of Archaeology. California: The Benjamin/Cummings Publishing Company, Inc. 1979.

Soebadio, Haryati. Arkeologi dan Pengembangan SosialBudaya Bangsa. Dalam Proceedings Pertemuan 1lmiah Arkeologi VI. Jakarta: Pusat Penelitian Arkeologi Nasional. Him. 3-13. 1993/1994. 
Widodo, Suko. "Mengkomunikasikan Makna Arkeologi Bagi Publik Dalam Konteks Kekinian” dalam Supratikno Rahardjo (ed.) Arkeologi Untuk Publik. Jakarta: IAAI. Hal: 33-38. 2012.

\section{Internet}

Anonim. "7 Langkah Mudah Membangun Home Recording Studio Dengan Bujet Rendah”. PT. Goshen Swara Indonesia, 12 November 2020.

https://www.goshen.co.id/detailberita/paket-home-recording-studio (diakses 15 November 2020)

Darnila, Nisrina. "Cara Mengatur Lighting Video Untuk Konten dalam Ruangan” . Penulis.id, 17 Desember 2018.

https://blog.penulis.id/id/cara-mengatur-lighting-video-untuk-konten-dalamruangan/ (diakses, 3 November 2020).

https://andi.link/hootsuite-we-are-social-indonesian-digital-report-2020/ (diakses, 1 November 2020)

https://www.statista.com/statistics/805656/number-youtube-viewersworldwide/(diakses, 5 November 2020)

https://www.thinkwithgoogle.com/consumer-insights/consumer-trends/self-learningyoutube-content-trends/(diakses, 5 November 2020)

Luthfi, Wihdi. "Podcast, Model Baru Konten YouTube". Good News From Indonesia. 10 Oktober 2019.

https:/www.goodnewsfromindonesia.id/2019/10/10/podcast-model-baru-konten-diyoutube (diakses, 6 November 2020) 